\title{
TEMNOSPONDYL DIVERSITY OF THE PERMIAN-TRIASSIC COLONIA OROZCO LOCAL FAUNA (BUENA VISTA FORMATION) OF URUGUAY
}

\author{
GRACIELA PIÑEIRO \\ Departamento de Evolución de Cuencas, Universidad de la República, Iguá 422, CP.11400, Montevideo, Uruguay. \\ fossil@fcien.edu.uy
}

CLAUDIA MARSICANO

Departamento de Ciencias Geológicas, Universidad de Buenos Aires, Ciudad Universitaria, Pab. II. Buenos Aires, Argentina.claumar@gl.fcen.uba.ar

\section{CÉSAR GOSO \& ELIZABETH MOROSI}

Departamento de Evolución de Cuencas, Universidad de la República, Iguá 422, CP.11400, Montevideo, Uruguay.

\begin{abstract}
Temnospondyls are the most abundant constituent of the Colonia Orozco Local Fauna of the Uruguayan Buena Vista Formation (Paraná Basin), contrasting with that observed at most latest Permian and earliest Triassic assemblages elsewhere. The components of the Colonia Orozco fauna, appear to represent early stages of the turnover evidenced in the communities of continental tetrapods at the Permo-Triassic boundary. They include plesiomorphic representatives of groups present in Early Triassic assemblages as well as relicts of Late Permian taxa. In particular, the presence of a close relative of the Russian dvinosauroid, Dvinosaurus, implies a dispersal event of this taxon to Gondwana probably during the Late Permian. Comparisons of the Colonia Orozco fauna to other Permo-Triassic communities indicate that it could be older than the Brazilian Lower Triassic Catuçaba Local Fauna of the Sanga do Cabral Formation (Paraná Basin) and probably equivalent to the latest Permian Russian Vyazniki Community. Moreover, the Colonia Orozco fauna could be close to the assemblages represented in the lowermost portion of the South African Lower Triassic Lystrosaurus Assemblage Zone and probably to the Arcadia Formation of Australia.
\end{abstract}

Key words: Temnospondyli, Colonia Orozco Local Fauna, Buena Vista Formation, latest Permian, earliest Triassic.

\begin{abstract}
RESUMO - Os Temnospondyli constituem o grupo mais abundante na Fauna Local de Colonia Orozco da Formação Buena Vista no Uruguay (bacia do Paraná), contrastando com o observado na maior parte das associações conhecidas em depósitos do final do Permiano e início do Triássico. A fauna de Colonia Orozco parece representar estágios primitivos da substituição faunística que se constata nas comunidades de tetrápodos continentais no límite Permo-Triássico. Os temnospondilos da Formação Buena Vista incluem representantes plesiomórficos de grupos presentes no início do Triássico, como também relictos de componentes típicos do Permiano superior. Entre eles se destaca a presença de um dvinosaurídeo proximamente relacionado com o gênero Dvinosaurus do Permiano superior da Rússia, o qual implicaría na existência de um evento de dispersão deste táxon até o Gondwana, provavelmente no Permiano Tardío. A comparação da Fauna de Colonia Orozco com outras asociaciones Permo-Triássicas, indica que a fauna uruguaya podería ser equivalente a Comunidad de Vyazniki do Permiano mais superior da plataforma russa, y que podería ostentar um status bastante próximo às associações presentes na porção mais basal da Zona de Lystrosaurus da África do Sul e na Formação Arcadia, na Austrália. Por outro lado, a Fauna Local de Colonia Orozco sería mais antiga que a Fauna Local de Catuçaba registrada na Formação Sanga do Cabral, bacia do Paraná (Brasil), considerada de idade Triássico inferior.
\end{abstract}

Palavras-chave: Temnospondyli, Fauna Local de Colonia Orozco, Formação Buena Vista, Permiano superior, Triássico inferior.

\section{INTRODUCTION}

The Buena Vista Formation crops out in north-eastern Uruguay (Figure 1) and was deposited under continental fluvial conditions, thus revealing an important environmental change from the brackish epicontinental sea that dominated the underlying Permian succession. The Buena Vista Formation consists of red brownish sandstones, intercalated with thin layers of red brownish mudstones and intraformational conglomerates (Bossi \& Navarro, 1991; Goso et al., 2001; Piñeiro \& Ubilla, 2003), which provided most of the known fossil specimens of the unit (Figure 2).

Although there is a general consensus among authors about the fluvial environmental characterization of the Buena Vista Formation, its age has remained contentious. For a long time, only one fossil specimen has been found in this formation (Marsicano et al., 2000), thus precluding good correlations with other fossiliferous Permo-Triassic 


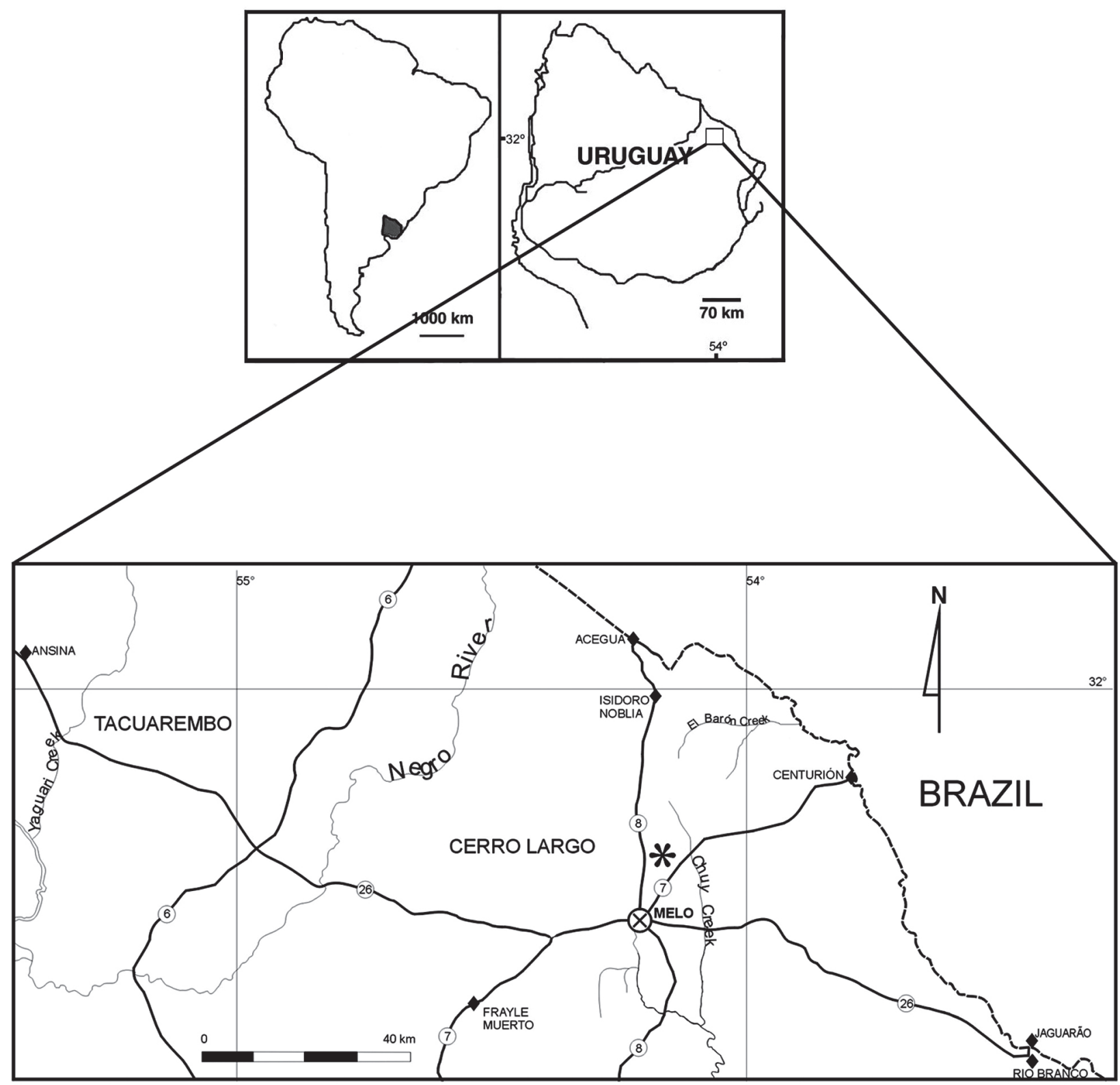

Figure 1. Detailed area at the Cerro Largo County, northeastern Uruguay, showing the location of the fossiliferous outcrop (asterisk) of the Buena Vista Formation.

successions like those of Brazil, South Africa, Australia and Russia. Therefore, the Triassic age previously assigned to the Buena Vista Formation was only based on lithostratigraphic similarities with the Sanga do Cabral Formation of southern Brazil (Bossi \& Navarro, 1991). Nevertheless, a significant tetrapod assemblage has recently been recovered from several localities of the Buena Vista Formation at Cerro Largo County. This assemblage appears to be different from that recovered in the Sanga do Cabral Formation, mainly in the presence of pelycosaurian-grade synapsids in the Uruguayan beds (Piñeiro et al., 2003, Piñeiro, 2004). In addition, the Buena Vista Formation has yielded procolophonoid and prolacertiform reptiles (Piñeiro et al., 2004; Piñeiro, 2004), and temnospondyl amphibians (Piñeiro, 2004; Piñeiro et al., 2007a,b), taxa which are also components of the Brazilian Catuçaba Local Fauna of the Sanga do Cabral Formation (Lavina, 1983; Barberena et al., 1985a; Cisneros \& Schultz, 2002; Abdala et al., 2002; Dias-da-Silva et al., 2005; 2006), although the Uruguayan fauna apparently represents an older assemblage (Piñeiro \& Ubilla, 2003; Piñeiro, 2004; Piñeiro et al., 2007a,b).

The aim of this paper is to provide an overview of the taxonomic composition of the temnospondyl fauna produced by the intraformational conglomerates of the Buena Vista Formation and to compare it to those described for other Pangaean regions, particularly South Africa, Brazil, Australia and Russia. In addition, the biostratigraphic and paleobiogeographic implications of the Uruguayan temnospondyls are discussed. 


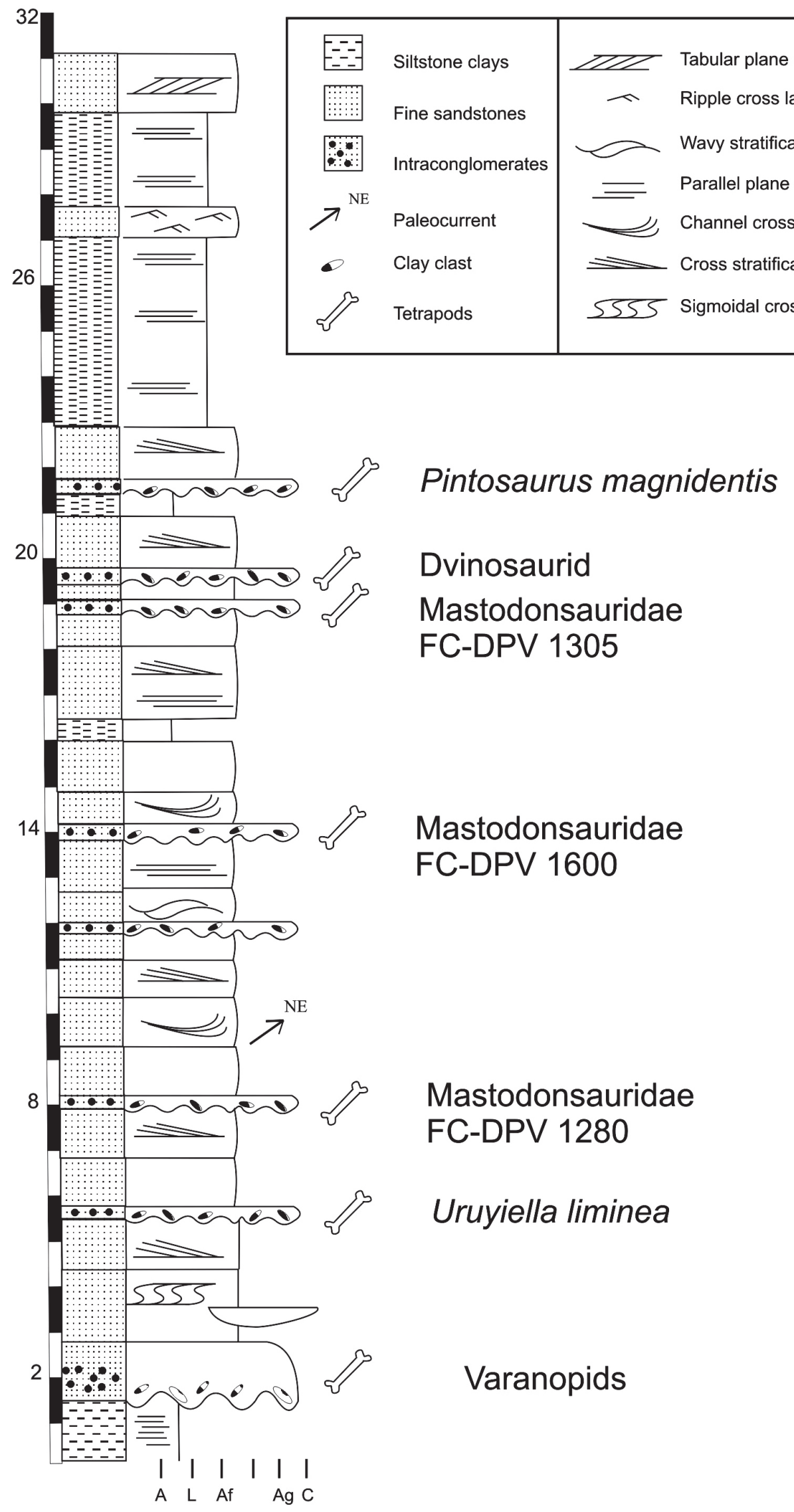

Figure 2. Combined profile of the Buena Vista Formation, including the stratigraphic sections present near the Colonia Orozco town, those along the Ruta $N^{\circ} 7$, and those around the Tres Boliches area, along the Ruta $N^{\circ} 8$. 


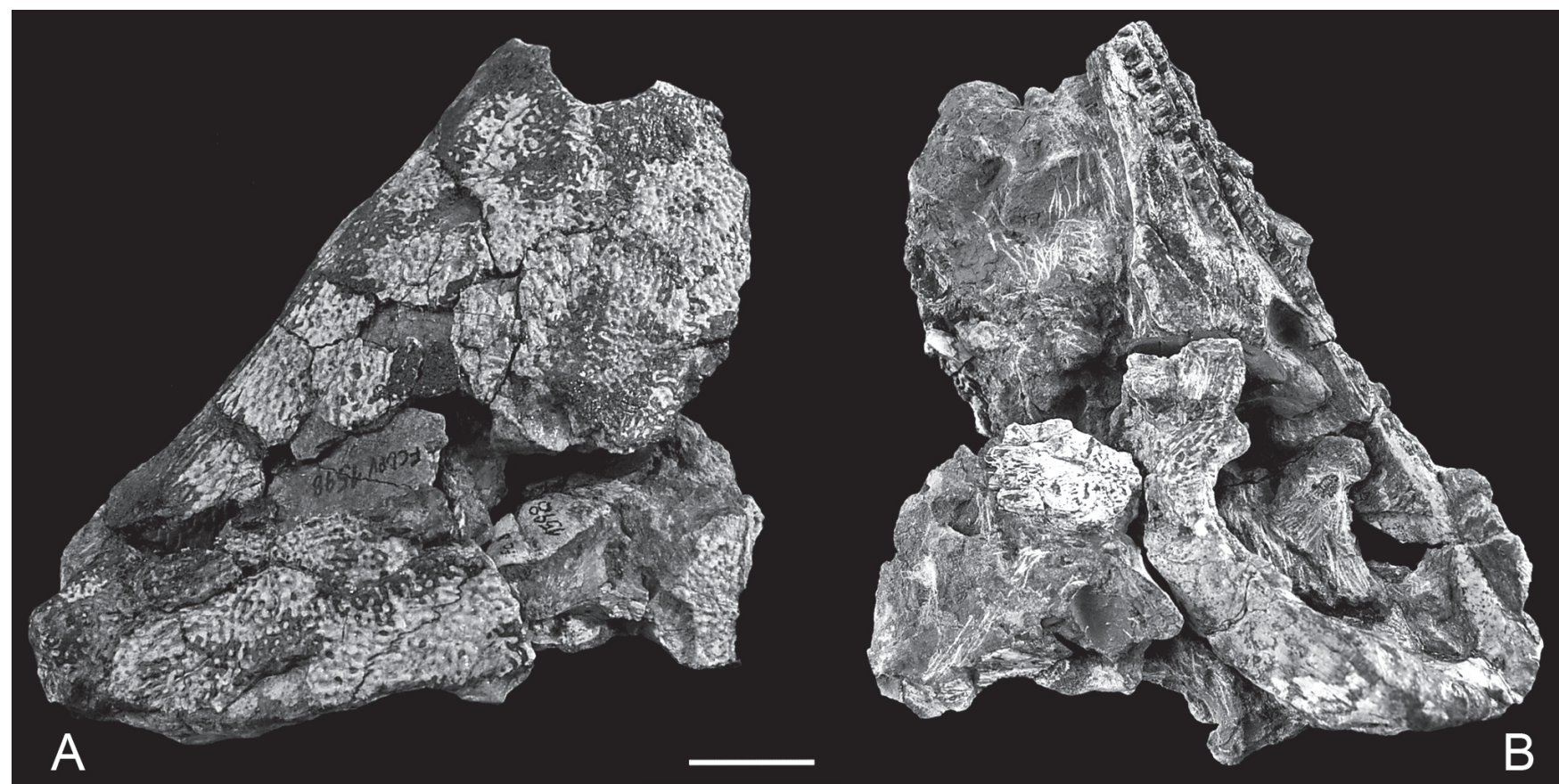

Figure 3. FC-DPV 1598, holotype of the laidleriid Uruyiella liminea from the lowermost intraformational conglomerates of the Buena Vista Formation (northeastern Uruguay), in dorsal (A) and ventral (B) views. Scale bar $=10 \mathrm{~mm}$.

\section{MATERIALS AND METHODS}

The materials on which we based this contribution are deposited in the Colección de Vertebrados Fósiles de la Facultad de Ciencias of Montevideo (FC-DPV), Montevideo (Uruguay). The comparative materials examined are from the Bernard Price Institute for Palaeontological Research of South Africa, examined by Claudia Marsicano, and from the Museu de Paleontologia, Fundação Zoobotânica do Rio Grande do Sul and the Instituto de Geociencias, Universidade Federal do Rio Grande do Sul (UFRGS) of Brazil, studied by Graciela Piñeiro and Claudia Marsicano.

\section{SYSTEMATIC PALAEONTOLOGY}

\section{TEMNOSPONDYLI LAIDLERIIDAE}

\section{Uruyiella liminea Piñeiro, Marsicano \& Lorenzo}

Material. FC-DPV 1598 (Figure 3), a partial skull from the lowermost intraformational conglomerates of the Buena Vista Formation at Colonia Orozco Town, Cerro Largo County, Uruguay

Remarks. According to both anatomical and phylogenetic studies, Uruyiella appears to lie close to the Lower or Middle Triassic species Laidleria gracilis of South Africa, due to the triangular shape of the skull, the ornamentation of the dermal bones and the lateral position of the orbits in both taxa (Piñeiro et al., 2007b). However, Uruyiella displays several autapomorphic characters which are not observed in any Triassic taxa. For instance, all the postorbital bones in Uruyiella are remarkably large and anteroposteriorly elongated, being almost twice as long as they are wide. This arrangement is observed in Trucheosaurus major from Australia (Marsicano \& Warren, 1998), the only known Permian rhytidosteid. Moreover, the palatine ramus of the pterygoid in Uruyiella extends well anteriorly, thus excluding the ectopterygoid and at least the posterior part of the palatine from the interpterygoid vacuity, a condition which is only comparable to that present in Palaeozoic temnospondyls (e.g. Watson, 1962; Gubin, 1991; Schoch \& Milner, 2000). On the other hand, the presence of a trough on the ventral surface of the quadratojugal which forms an 'overhang' in occipital view in Uruyiella and Laidleria, is a characteristic that they share with the plagiosaurids. It is important to note that the phylogenetic affinities of both Laidleria and the plagiosaurids have been the subject of controversy among authors. Laidleria was alternatively considered as a trematosaurid by Kitching (1957), a laidleriid within the superfamily Rhytidosteoidea (Cosgriff, 1965, 1974), or as a member of a different family (Laidleriidae) within Temnospondyli (Cosgriff \& Zawiskie, 1979). The plagiosaurids in turn have been recognized as stem Lissamphibia close to Peltobatrachus (Milner, 1990). A recent comprehensive study of temnospondyl relationships showed that Laidleria and the plagiosaurids are closely related taxa within the Stereospondyli (Yates \& Warren, 2000); however, a new analysis including Uruyiella indicated that all these taxa form a clade related to the Dvinosauria, and that they fall outside the Stereospondyli (Piñeiro et al., 2007b). 


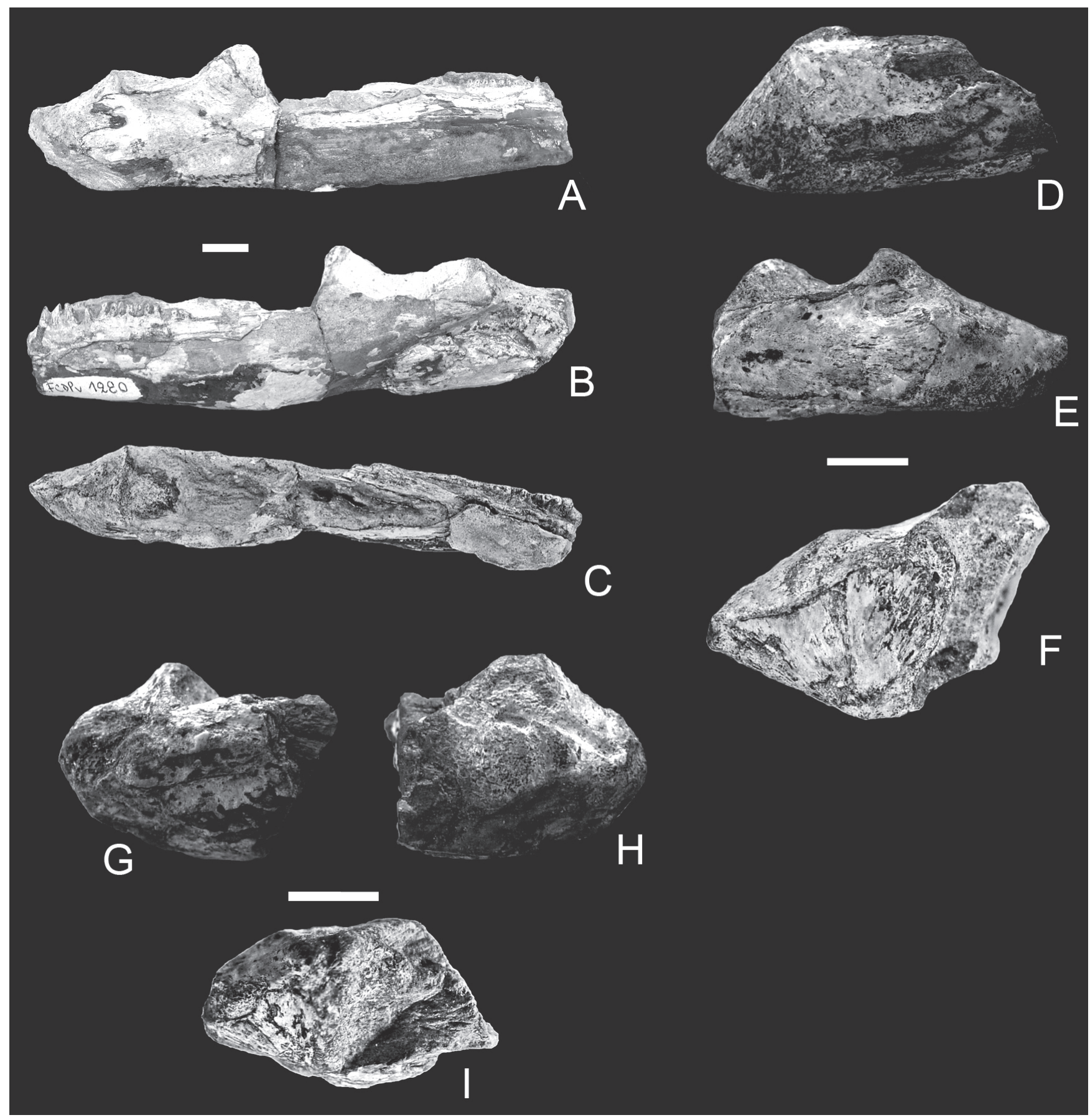

Figure 4. Mastodonsaurid mandibles from the intraformational conglomerates of the Buena Vista Formation (northeastern Uruguay): A-C, FC-DPV 1280, partial left mandible in labial (A), lingual (B) and dorsal (C) views; D-F, FC-DPV 1600, post glenoid area (PGA) of a rigth mandible in labial (D), lingual (E) and dorsal (F) views; G-I, FC-DPV 1305, PGA of a left mandible in labial (G), lingual (H) and dorsal (I) views. Scale bars $=10 \mathrm{~mm}$.

\section{TEMNOSPONDYLI MASTODONSAURIDAE}

Materials. FC-DPV 1280, 1305, 1600 (Figure 4); partial mandibles preserving the post-glenoid area (PGA), from middle and upper conglomerate levels of the Buena Vista Formation at Colonia Orozco town, Cerro Largo County, Uruguay.

Remarks. The fragmentary nature of the materials and the absence of associated skulls preclude a more precise taxonomic assignation. The placement of these specimens within Mastodonsauridae is supported by the distinctive morphology of the PGA, the nature of its dorsal muscular crests, and by the presence of a well developed hamate process. Although their general morphology is consistent with that described for most basal members of Mastodonsauridae (sensu Damiani, 2001), the Uruguayan mandibles may represent new taxa that display some 


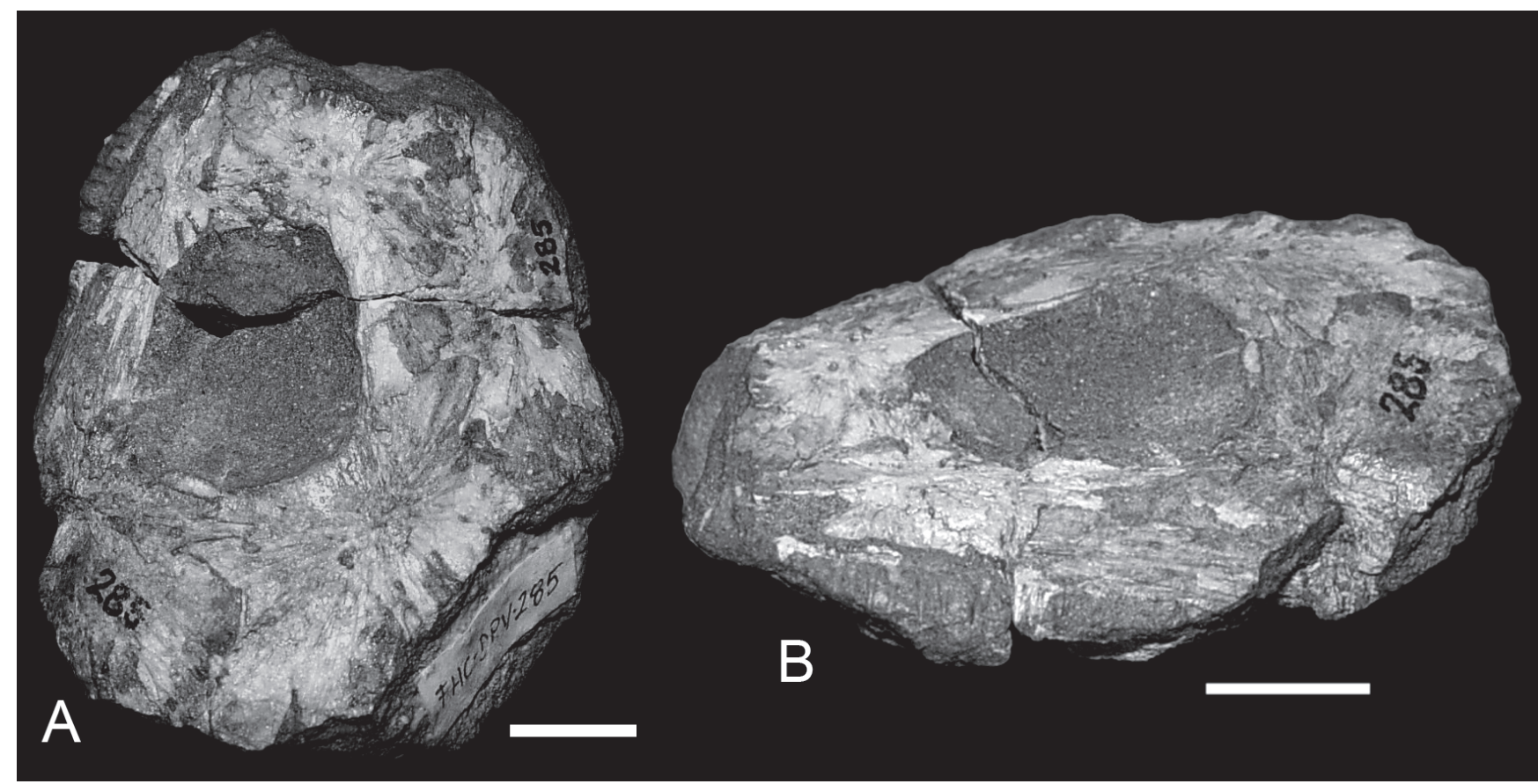

Figure 5. FC-DPV 285, dvinosaurid skull fragment including the left orbit, from the uppermost intraformationalconglomerates of the Buena Vista Formation, in dorsal (A) and lateral (B) views. Scale bar $=10 \mathrm{~mm}$.

characters not previously described in Mesozoic temnospondyls. Among them, the presence of a continuous tooth row on at least the posterior and middle coronoids appears to be convergent with the Late Permian rhinesuchids of southern Brazil (personal observation, Piñeiro et al., 2007a).

\section{TEMNOSPONDYLI}

DVINOSAURIA (sensu Yates \& Warren, 2000)

Material. FC-DPV 285 (Figures 5, 6). A partial skull, preserving part of the skull table at the level of the left orbital region. It comes from intraformational conglomerates of the Buena Vista Formation exposed at the wedge of Ruta $\mathrm{N}^{\circ} 7$, Cerro Largo County, Uruguay.

Remarks. This skull fragment was the first specimen discovered in the Buena Vista Formation and for a long time it was the only known fossil from this unit (Marsicano et $a l ., 2000)$. The fragmentary nature of the specimen precludes a precise taxonomic assignation, but regarding its short and broad skull and the presence of a bone which forms the anterolateral margin of the orbit in the position of the lacrimal or the lateral exposure of the palatine (LEP) (Figure $6)$, the material was related to the DvinosaurusTupilakosauridae clade (Marsicano et al., 2000). The poor preservation of the skull hamper a secure identification of that bone as the lacrimal. On the one hand, it displays the same ornamentation of the other preserved skull table elements as occurs in those taxa where the lacrimal is present. Tupilakosaurids display the unusual condition among temnospondyls of a large postorbital that contacts both the frontal (Milner \& Sequeira 2004) and the parietal
(Warren, 1999) because of the unusually small size of the postfrontal. This condition is not observed in FC-DPV 285, which in turns shows a large postfrontal in contact with the prefrontal, thus precluding the frontal from contacting the postorbital and also excluding it from the orbital margin (Figures 5A, 6). The absence of a postorbital-parietal contact can be also inferred because the postorbital is laterally displaced by the large postfrontal, and thus does not contact the parietal. Among brachyopids, which also have a short and parabolic skull, the lacrimal and the LEP are absent in most cases, and only the Russian Batrachosuchoides lacer and the Australian Xenobrachyops allos have a LEP (Shishkin, 1967; Damiani \& Warren, 1996). As the only known specimen of Batrachosuchoides consists of an antorbital area of a skull, the configuration of the postorbital bones cannot be compared to that present in FC-DPV 285. Along with the presence of a LEP, Batrachosuchoides shares some other characters with dvinosaurians (see Warren, 1999; Warren and Marsicano, 2000; Marsicano et al., 2000), thus its affinities will remain unclear until more complete specimens can be discovered. Therefore, we consider the skull bone configuration present in FC-DPV 285 as more consistent with that described for the Permian Dvinosaurus (Bystrow, 1938) than for tupilakosaurids and brachyopids.

\section{DISCUSSION}

\section{Geological overview of the Buena Vista Formation}

Currently, the succession that includes the end of the Permian and probably the beginning of the Triassic in Uruguay is represented by two units, the Yaguarí and the 


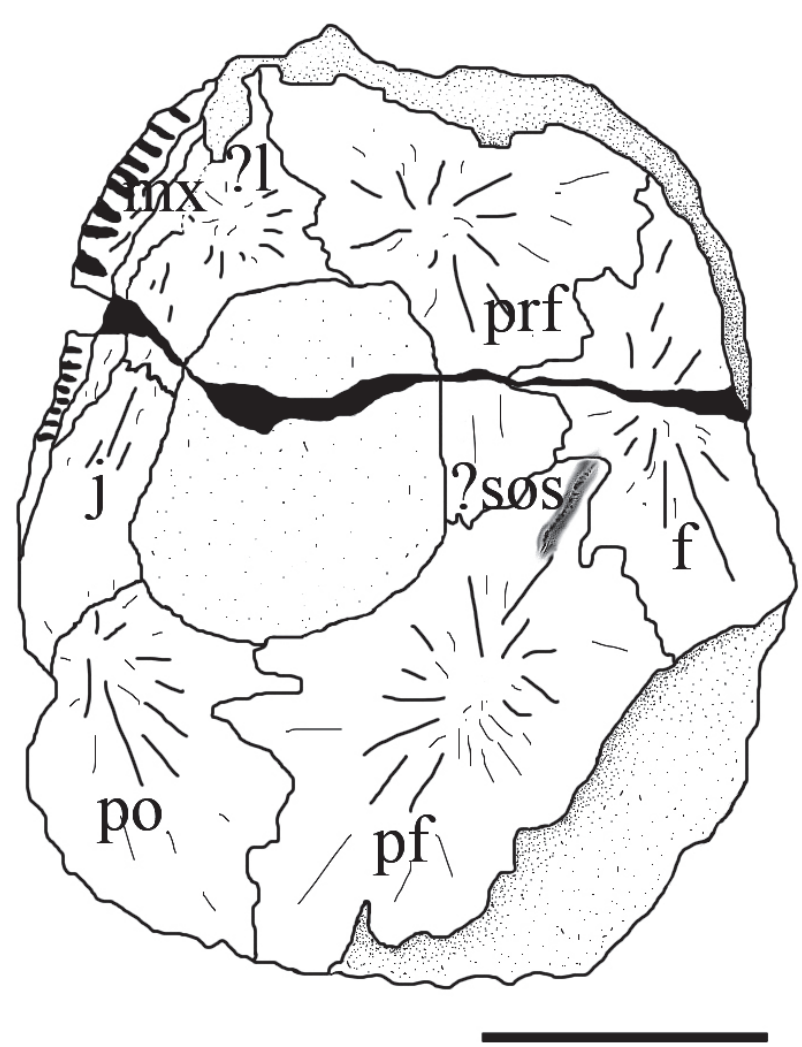

Figure 6. Interpretive drawing of FC-DPV 285 in dorsal view, showing the presence of a probable lacrimal and also the morphology of the preserved prefrontal, postfrontal and postorbital (see text). Abbreviations: f, frontal; j, jugal; I, lacrimal; $\mathbf{m x}$, maxilla; pf, postfrontal; prf, prefrontal; po, postorbital; sos, supraorbital sulcus.

Buena Vista formations. For a long time both the characterization and the age of these units have been the subject of controversy among authors (see Falconer, 1937; Delaney \& Goñi, 1963). The difficulty in establishing the boundary between the Yaguarí Formation and the overlying Buena Vista Formation lead some geologists to consider them as a single unit, assigned to the Upper Permian (e.g. Falconer, 1937; Bossi, 1966; Elizalde et al., 1970). Other authors, in turn, differentiated the red, mostly arenaceous upper portion of the succession as an independent and well defined unit, the Buena Vista Formation, which was considered to represent the Lower Triassic in Uruguay (Caorsi \& Goñi, 1958; Ferrando \& Andreis, 1986; Bossi \& Navarro, 1991), although no fossils were yet discover from it.

At present, local and regional stratigraphic studies support the recognition of the Buena Vista Formation as a separate unit from the Yaguarí Formation (Goso et al., 2001; de Santa Ana, 2005), but the tetrapod assemblage recently found in the Buena Vista Formation, designated the Colonia Orozco Local Fauna by Piñeiro \& Ubilla (2003) and Piñeiro (2004), points to an older age than that previously recognized, closer to the Permian-Triassic boundary (Piñeiro et al., 2003; Piñeiro \& Ubilla, 2003; Piñeiro, 2004; Piñeiro et al., 2004; Piñeiro et al., 2007b).

\section{Biostratigraphic relations of the Colonia Orozco Local} Fauna with other Pangaean communities

The Catuçaba Local Fauna of the Brazilian Sanga do Cabral Formation. The lithological similarities observed between the Uruguayan Buena Vista and the Brazilian Sanga do Cabral formations, in addition to the fact that both are part of the infilling of the Paraná Basin, strongly suggested that they could be stratigraphic equivalents. Nevertheless, the Uruguayan Colonia Orozco Local Fauna does not seem to be contemporaneous with the Catuçaba Local Fauna of the Brazilian Sanga do Cabral Formation. In particular, their temnospondyls and procolophonoid reptiles show important differences (Piñeiro \& Ubilla, 2003; Piñeiro et al., 2004). Thus, Pintosaurus magnidentis, at present the only described procolophonoid from the Buena Vista Formation, is more closely allied to the basal representatives known from the Lower Triassic of South Africa and Russia (Piñeiro, 2004; Piñeiro et al., 2004) than to Procolophon, the most common taxon in the Catuçaba Local Fauna (Lavina, 1983; Barberena et al., 1985a; Cisneros \& Shultz, 2002; Dias-da-Silva et al., 2006; Cisneros, in press).

The temnospondyl composition at the Brazilian Sanga do Cabral Formation includes probable lydekkerinids and rhytidosteids (Lavina \& Barberena, 1985; Dias-da-Silva et al., 2005; 2006) which are absent in the Buena Vista fauna. Both groups are widely represented in Early Triassic successions in Gondwana (e.g.Yates \& Warren, 2000; Damiani, 2001; Damiani \& Yates, 2003) and there is an isolated record of Rhytidosteidae from Upper Permian deposits of Australia (Marsicano \& Warren, 1998). This evidence, in addition to the presence of Procolophon in the Sanga do Cabral beds, strongly suggest an Early Triassic age for this unit. This is in concordance with the 'impoverished zone' or Procolophon subzone sensu Neveling et al. (1999) recognized in the South African Permo-Triassic succession (Cisneros \& Schultz, 2002; Dias-da-Silva et al., 2006).

In contrast, the Uruguayan Colonia Orozco fauna includes some temnospondyl taxa that although related to essentially Triassic groups (e.g. Laidleriidae and Mastodonsauridae), they possess several features that locate them in basal positions within those groups (Piñeiro et al., 2007a,b). In addition, the presence in the Colonia Orozco fauna of a temnospondyl probably related to the Russian taxon Dvinosaurus, an exclusively Late Permian taxon, indicates that the age of that assemblage is older than the Brazilian fauna and might be placed in the Late Permian or close to the Permian-Triassic boundary.

The chronological hypothesis discussed above is also corroborated by recent radiometric studies on bentonite ashes from the Yaguarí Formation (de Santa Ana et al., 2006), which place this unit in the Middle Permian $(269.8 \pm 4.7 \mathrm{Ma})$. Considering its conformable contact with the Buena Vista Formation, an Early Triassic age for the latter unit becomes improbable.

It is important to remark that recent radiometric data from the Upper Paleozoic Brazilian succession revealed older 
ages for the constituent units than those previously assigned to them. For instance, zircons from the Iratí Formation indicate an Early Permian (Cisuralian) age for this unit (Ventura-Santos et al., 2006) which is significantly older than the Late Permian (old Guadalupian) age traditionally assigned to it (e.g. Daemon \& Quadros, 1970). This has resulted in a new stratigraphic scheme where the Rio do Rasto Formation (the unit that stratigraphically underlies the Sanga do Cabral Formation) is placed mostly within the Guadalupian (268.0 \pm 0.7 Ma, Middle Permian) (VenturaSantos et al., 2006), thus contrasting with most previous studies which placed the Rio do Rasto Formation entirely within the Late Permian (e.g. Barberena et al., 1985a; Barberena et al., 1985b; Langer, 2000). The contact between the Rio do Rasto and Sanga do Cabral formations was described as conformable by some authors (Gamermann, 1973; Faccini, 1989), but in more recent studies it has been regarded as not conformable (Scherer et al., 2000; Zerfass et al., 2003). However, this disagreement may be because of 'missing' stratigraphy in some places where the contact is described (Faccini, 1989).

Most of the fossils recovered from both the Sanga do Cabral Formation in Brazil and from the Buena Vista Formation in Uruguay come from intra-formational conglomerate levels present in both units. Two bodies of conglomerates separated by a thin mudstone layer have been described for the Sanga do Cabral Formation by Zerfass et al. (2003), correlating the upper body with the fossiliferous Procolophon Range Zone from South Africa. Taking into account the differences in faunal composition between the Uruguayan and the Brazilian units, it seems possible that the fossiliferous conglomerates present in the Buena Vista Formation correspond to the lower body, therefore explaining the older age suggested by its tetrapods. As the mapped area of the Sanga do Cabral Formation suggests topographic highs to the west (Zerfass et al., 2003), it is possible that the upper body of conglomerates is not present in Uruguay (César Schultz, pers. comm. 2007). In fact, the isopachic map that includes the Buena Vista Formation shows that it increases its thickness to the northwest portion of the basin, where it attains more than 600 meters thickness (de Santa Ana et al., 2006), contrasting with the sharply erosive processes that can be seen near the Colonia Orozco town, at the eastern part of the basin. That erosion is related to the late Hercinian tectonic activities produced in the inner cratonic Gondwana (Cobbold et al., 1992).

Lystrosaurus Assemblage Zone of South Africa. P ermi a n and Triassic terrestrial strata are represented in the South African Karoo Basin and their fossil vertebrates were the subject of several recent papers (Ward et al., 2000, 2005; Smith \& Ward, 2001; Steiner et al., 2003; Smith \& Botha, 2005; Botha \& Smith, 2006). According to these studies, the uppermost Permian strata (Dicynodon Assemblage Zone; Lower Palingkloof Member of the Balfour Formation) have yielded non mammalian therapsids (e.g. Dicynodon,
Lystrosaurus maccaigi and Moschorhinus), but temnospondyl remains have not been found in that deposits at present. The Early Triassic is represented in several localities by the tetrapods of the Lystrosaurus Assemblage Zone (upper Palingkloof Member of the Balfour Formation and the overlying Katberg Formation) where the therapsid Lystrosaurus is the most common taxon (Botha \& Smith, 2006). However, a lowermost Triassic locality at Barendskraal shows a different faunal composition (Damiani et al., 2003), dominated by basal procolophonoids (Modesto et al., 2001, 2003, Modesto \& Damiani, 2007; Reisz \& Scott, 2002) and other amniote taxa, but temnospondyls appear still to be absent. With the exception of the dissorophid Micropholis, which first record is in the upper Palingkloof Member and the lydekkerinid Lydekerina, which is for the first time recorded in the basal Katberg Formation (Smith \& Botha, 2005; Botha \& Smith, 2006), the stratigraphic position of the remaining temnospondyl taxa in the Karoo (Rhinesuchidae, Tupilakosauridae, Rhytidosteidae, Mastodonsauridae and Trematosauridae) is poorly constrained (Damiani, 2004). Rhinesuchidae are characteristic in Permian strata, while lydekkerinids (particularly represented by Lydekkerina huxleyi) are a conspicuous component of the Lower Triassic beds (Rubidge et al., 1995). None of these taxa have been found in the Colonia Orozco Fauna at present, neither other characteristic Triassic temnospondyls of the Karoo as rhytidosteids, tupilakosaurids and trematosaurids. Despite the Uruguayan mastodonsaurids display a similar morphology to that found in basal Triassic representatives of this group, they appear to be more plesiomorphic (Piñeiro et al., 2007). Nevertheless, this hypothesis needs to be confirmed by the discovery of more complete specimens in the Uruguayan beds.

The Early Triassic Arcadia Formation of Australia. The Permo-Triassic succession in Australia is represented by the Rewan Group, which includes the Upper Permianlowermost Triassic Sagittarius Sandstone conformably overlied by the Lower Triassic Arcadia Formation (Warren et al., 2006). The age of the Sagittarius Sandstone is supported by palinological and radiometric data (Foster, 1982; Archbald \& Dickens, 1996 in Warren et al., 2006) thus suggesting an earlier Triassic age than that previously proposed for the Arcadia Formation, closer to the P-T boundary (Warren et al., 2006). Nevertheless and according to Warren et al., (2006), the P-T boundary in Australia remains controversial. The recent discovery of the temnospondyl Lydekkerina huxleyi in the Arcadia Formation might help to constrain the age of this unit. In South Africa Lydekkerina has been recovered from the lower part of the Lystrosaurus Assemblage Zone, thus suggesting a probable correlation between the Arcadia Formation and the lower part of the Katberg Formation of South Africa (Warren et al., 2006). This hypothesis is supported by the presence of taxa as the Lapillopsidae, which display a basal position in most recent temnospondyl phylogenies (Yates, 
1999; Yates \& Warren, 2000) and also by some plesiomorphic representatives of known Triassic groups (Warren et al., 2006).

This situation could be comparable with that seen in the Colonia Orozco fauna, but it remains rather different if we consider that unambiguous Triassic fossil index are absent from the Uruguayan community.

The Vyazniki community from Russia. In Russia, the uppermost Permian is represented in the Vyazniki Community (Vyatkian Horizon) (Sennikov, 1996; Sennikov \& Golubev, 2006), which seems to be different to other Late Permian continental faunas from Pangaea (Sennikov, 1996; Sennikov \& Golubev, 2006). Tetrapods and other groups from Vyazniki include taxa that are characteristic in Late Permian communities, together with taxa known to be present in the Early Triassic, a feature that was used to infer a transitional status for this Russian assemblage (Sennikov, 1996; Sennikov \& Golubev, 2006).

A similar condition is observed for the Colonia Orozco fauna, where a mixture of continental tetrapods including some putative Permian groups (e.g. varanopids and Dvinosaurus-type temnospondyls) and earlier components of well established Early Triassic taxa (e.g. Laidleriidae and Mastodonsauridae) are found. Although pareiasaurids have not yet been recovered from the Buena Vista levels, this might not be a relevant difference between both assemblages as this group is consider relictual in the Vyazniki Community, only represented by few elginiid taxa (see Sennikov \& Golubev, 2006).

While Dvinosaurus is a typical taxon in the Russian Vyazniki Assemblage (Goluveb, 2000; Sennikov \& Golubev, 2006), it is not registered in the overlying Lower Vetluga Community, which represents the beginning of the Triassic in that area. Thus, the presence of a Dvinosaurus-like temnospondyl in the Buena Vista Formation of Uruguay could represent, as for the Russian Vyazniki community, the latest known record of this taxon close to the P-T boundary. It also suggests a dispersal event for dvinosaurians between Russian and South American areas at the end of the Permian, where they could have survived in refuges until the very end of the Permian or even until the beginning of the Triassic.

This biogeographic hypothesis was already established by several authors and largely documented by taxonomical similarities found between Russian and South African therapsids (Ochev \& Shishkin, 1989; Milner, 1990; Warren, 1999, Yates \& Warren, 2000; Battail, 2000; Sidor et al., 2005; Surkov et al., 2005; Smith et al., 2006; Shishkin et al., 2006).

\section{CONCLUSIONS}

Temnospondyls were a conspicuous and abundant component of the Uruguayan Colonia Orozco Fauna, thus contrasting with that observed in the lowermost Triassic of South Africa, where this group of tetrapods was not yet found.
Analyses of the Colonia Orozco temnospondyls show that they include Permian and Triassic lineages, thus suggesting a transitional status for this fauna, as also occurs in the latest Permian Russian Vyazniki Community. Therefore, the previously suggested Permo-Triassic age for the fossiliferous conglomerates of the Buena Vista Formation is also supported by its temnospondyl fauna.

Dvinosaurus-type temnospondyls seem to have been present in the Colonia Orozco Fauna representing the first record of this taxon in Gondwanan areas of Pangaea, and probably its latest known record. Considering both the presence of Dvinosaurus in Eastern Europe and Dvinosauruslike temnospondyls in Gondwana, a probable faunal connection between these two geographically distant areas during the Permian is proposed, as it was also inferred by similar therapsid taxa present in both South African and Russian Permo-Triassic deposits.

\section{ACKNOWLEDGMENTS}

The authors are grateful to Y. Pardiñas for his hospitality and help during fieldwork at Cerro Largo County; to M. Verde, A. Rojas, M. Ubilla, D. Picchi and F. Kuczera for collaboration in the fieldwork. They also thank to A. Warren for comments for determination of the affinities of FC-DPV 285 and providing us with valuable literature, and to F. Abdala for the reading and improvement of the manuscript. To R. Damiani and an anonymous reviewer for their important suggestions, which highly improved this paper. This study was supported by the Dirección Nacional de Ciencia y Tecnología, Programa de Desarrollo Tecnológico operating grant 29/104 (GP and CG); and PIP-CONICET 5120 (CM).

\section{REFERENCES}

Abdala, F.; Dias-Da-Silva, S. \& Cisneros, J.C. 2002. First record of non-mammalian cynodonts (Therapsida) in the Sanga do Cabral Formation (Early Triassic) of Southern Brazil. Palaeontologia Africana, 38:92-97.

Barberena, M.C.; Araújo, D.C. \& Lavina, E.L. 1985a. Late Permian and Triassic tetrapods of Southern Brazil. National Geographic Research, 1:5-20.

Barberena, M.C.; Araújo, D.C.; Lavina, E.L. \& Azevedo, S.A.K. 1985b. O estado atual do conhecimento sobre os tetrápodos Permianos e Triássicos do Brasil Meridional. In: Coletânea de Trabalhos Paleontológicos, Rio de Janeiro, MME-DNPM, p. 21-28 (Série Geologia 27).

Battail, B. 2000. A comparison of late Permian Gondwanan and Laurasian faunas. Journal of African Earth Sciences, 31:165174.

Bossi, J. 1966. Geología del Uruguay. Montevideo, Departamento de Publicaciones, Universidad de la República, 411 p.

Bossi, J. \& Navarro, R. 1991. Geología del Uruguay. Montevideo, Departamento de Publicaciones, Universidad de la República, $970 \mathrm{p}$.

Botha, J. \& Smith, R.M.H. 2005. Rapid vertebrate recuperation in the Karoo Basin of South Africa following the End-Permian extinction. Journal of African Earth Sciences, 45:502-514. 
Bystrow, A.P. 1938. Dvinosaurus als neotenische form der Stegocephalen. Acta Zoologica, 19:209-295.

Caorsi, J. \& Goñi, J. 1958. Geología uruguaya. Boletín del Instituto Geológico del Uruguay, 37:1-73.

Cisneros, J.C. In press. Taxonomic status of the reptile genus Procolophon from the Gondwanan Triassic. Palaeontologia Africana.

Cisneros, J.C. \& Schultz, C.L. 2002. Procolophon brasiliensis n. sp., a new procolophonid reptile from the Lower Triassic of southern Brazil. Neues Jahrbuch für Geologie und Paläontologie Monatshefte, 2002:641-648.

Cobbold, P.R.; Gapais, E.; Rossello, E.A.; Milani, E.J. \& Szatmari, P. 1992. Permo-Triassic intracontinental deformation in SW Gondwana. In: M.J. de Witt \& I.D Ransome (eds.) Inversion tectonics of the Cape Fold Belt, Karoo and Cretaceous basins of Southern Africa, Balkema, p. 23-26.

Cosgriff, J.W. 1965. A new genus of Temnospondyli from the Triassic of Western Australia. Journal of the Royal Society of Western Australia, 48:65-90.

Cosgriff, J.W. 1974. Lower Triassic Temnospondyli of Tasmania. Geological Society of America, Special Paper, 149:1-134.

Cosgriff, J.W. \& Zawiskie, J.M. 1979. A new species of the Rhytidosteidae from the Lystrosaurus Zone and a review of the Rhytidosteoidea. Palaeontologia Africana, 22:1-27.

Daemon, R.F. \& Quadros, L.P. 1970. Bioestratigrafia do Neopaleozóico da Bacia do Paraná. In: CONGRESSO BRASILEIRO DE PALEONTOLOGIA, 24, 1970. Anais, Brasília, SBP, p. 359-412.

Damiani, R.J. 2001. A systematic revision and phylogenetic analysis of Triassic mastodonsauroids (Temnospondyli: Stereospondyli). Zoological Journal of the Linnean Society, 133:379-482.

Damiani, R.J. 2004. Temnospondyls from the Beaufort Group (Karoo Basin) of South Africa and their biostratigraphy. Gondwana Research, 7:165-173.

Damiani, R.J. \& Warren, A.1996. A new look at members of the Superfamily Brachyopoidea (Amphibia, Temnospondyli) from the Early Triassic of Queensland and a preliminary analysis of brachyopoid relationships. Alcheringa, 20:277300.

Damiani, R.J. \& Yates, A.M. 2003. The Triassic amphibian Thoosuchus yakovlevi and the relationships of the Trematosauroidea (Temnospondyli: Stereospondyli). Records of the Australian Museum, 55:331-342.

Damiani, R.J.; Neveling, J.; Modesto, S.P \& Yates, A. 2003. Barendskraal, a diverse amniote locality from the Lystrosaurus Assemblage Zone, Early Triassic of South Africa. Palaentologia Africana, 39:53-62.

Delaney, P.J. \& Goñi, J. 1963. Correlação preliminar entre as Formações Gondwânicas do Uruguai e Rio Grande do Sul, Brasil. Boletim Paranense de Geografia, 8/9:3-20.

De Santa Ana, H. 2005. Análise tectono-estratigráfica das seqüencias Permo-Triassica e Jurocretácea da Bacia Chacoparanense uruguaia (Cuenca Norte). Curso de PosGraduação em Geociências, Universidade Estadual Paulista, $\mathrm{PhD}$ Dissertation, $274 \mathrm{p}$.

De Santa Ana, H.; Goso, C. \& Daners, G. 2006. Cuenca Norte: estratigrafía del Carbonífero y Pérmico. In: G.Veroslavsky; M. Ubilla \& S. Martínez (eds). Cuencas Sedimentarias de Uruguay: Geología, Paleontología y Recursos Minerales, Paleozoico, Dirac, p.147-208.

Dias-Da Silva, S.; Marsicano, C. \& Schultz, C. 2005. Early Triassic temnospondyl skull fragments from southern South America (Paraná Basin, Brazil). Revista Brasileira de Paleontologia, 8:43-50.

Dias-Da Silva, S.; C., Marsicano, C. \& Schulz, C. 2006. A new rhytidosteid (Temnospondyli, Stereospondyli) from southern South America (Lower Triassic of Brazil). Palaeontology, 49:381-390.

Elizalde, G.; Eugui, W.; Verdesio, J.; Stapff, M. \& Tellechea, J. 1970. Carta Geológica del Uruguay a escala 1/100.000.3, segmento Aceguá, sector XXX. Montevideo, Universidad de la República, 127 p. (Boletín 3).

Faccini, U.F. 1989. O Permo-Triássico do Rio Grande do Sul. Uma análise sob o ponto de vista das seqüencias deposicionais. Programa de Pós-Graduação em Geociências, Universidade Federal do Rio Grande do Sul, Master Thesis, $113 \mathrm{p}$.

Falconer, J.D. 1937. La Formación Gondwana en el NE del Uruguay, con especial referencia a los terrenos eogondwánicos. Boletín del Instituto de Geología y Perforaciones del Uruguay, 23:1-113.

Ferrando, L. \& Andreis, R. 1986. Nueva estratigrafía en el Gondwana de Uruguay. In: I CONGRESO LATINOAMERICANO DE HIDROCARBUROS, 1, 1986. Actas, Buenos Aires, 1:295323.

Foster, C.B. 1982. Spore pollen assemblages of the Bowen Basin, Queensland (Australia): their relationship to the PermoTriassic boundary. Review of Palaeobotany and Palinology, 36:165-183.

Gamermann, N. 1973. Formação Rosário do Sul. Pesquisas, 2:536.

Golubev, V.K. 2000. The faunal assemblages of Permian terrestrial vertebrates from Eastern Europe. Palaeontological Journal, 33:185-202.

Goso, C.; Piñeiro, G.; De Santa Ana, H.; Rojas, A.; Verde, M. \& Alves, C. 2001. Caracterización estratigráfica de los depósitos continentales cuspidales neopérmicos (Formaciones Yaguarí y Buena Vista) en el borde oriental de la Cuenca Norte Uruguaya. In: CONGRESO LATINOAMERICANO DE GEOLOGÍA, 11, 2001. Actas, Montevideo, 18 p. (CDROM).

Gubin, Y.M. 1991. Permian archegosauroid amphibians of the USSR. Trudy Paleontologischeskogo Instituta, 249:1-138. [in Russian]

Kitching, J.W. 1957. A new small stereospondylous labyrinthodont from the Triassic beds of South Africa. Palaeontologia Africana, 5:67-82.

Kitching, J.W. 1978. The stratigraphic distribution and ocurrence of South African fossil Amphibia in the Beaufort Beds. Palaeontologia Africana, 21:101-112.

Lavina, E.L. 1983. Procolophon pricei sp.n. um novo procolophonideo do Triássico do Rio Grande do Sul. Iheringia, 2:51-78.

Lavina, E.L \& Barberena, M.C. 1985. Anfibios ritidosteidos y lidekkerinideos da Formação Sanga do Cabral (Triásico Inferior do Rio Grande do Sul). Implicações bioestratigráficas y geocronológicas. Iheringia, Série Geologia, 10:19-27.

Langer, M. 2000. The first record of dinocephalians in South America: Late Permian (Rio do Rasto Formation) of the Paraná Basin, Brazil. Neues Jahrbuch für Geologie und Paläontologie Abhaundlungen, 215(1):69-95.

Marsicano, C. \& Warren, A. 1998. The first Palaeozoic rhytidosteid record: Trucheosaurus major Watson 1956 from 
the Late Permian of Australia, and a reassessment of the Rhytidosteidae (Amphibia, Temnospondyli). Bulletin of the British Museum (Natural History), Geology, 54:147-154.

Marsicano, C.; Perea, D. \& Ubilla, M. 2000. A new temnospondyl amphibian from the Lower Triassic of South America. Alcheringa, 24:119-123.

Milner, A.R. 1990. The radiation of temnospondyl amphibians. Systematics Association Special Volume, 42:321-349.

Milner, A.R. \& Sequeira, S.E.K. 2004. Slaugenhopia texensis (Amphibia: Temnospondyli) from the Permian of Texas is a primitive tupilakosaurid. Journal of Vertebrate Paleontology, 24:320-325.

Modesto, S.P.; Sues, H.-D. \& Damiani, R.J. 2001. A new Triassic procolophonoid reptile and its implications for procolophonoid survivorship during the Permo-Triassic extinction event. Proccedings of the Royal Society of London, B 268:2047-2052.

Modesto, S.P.; Damiani, R.J.; Neveling, J. \& Yates, A.M. 2003. A new Triassic owenettid parareptile and the Mother of Mass Extinctions. Journal of Vertebrate Paleontology, 23:715-719.

Modesto, S.P. \& Damiani, R.J. 2007. The procolophonoid reptile Sauropareion anoplus from the lowermost Triassic of South Africa. Journal of Vertebrate Paleontology, 27:337-349.

Neveling, J.; Rubidge, B.S. \& Hancox, P.J. 1999. A lower Cynognathus Assemblage Zone fossil from the Katberg Formation (Beaufort Group, South Africa). South African Journal of Science, 95:555-556.

Ochev, V.G. \& Shishkin, M.A.1989. On the principles of global correlation of the continental Triassic on the tetrapods. Acta Palaeontologica Polonica, 31:149-173.

Piñeiro, G. 2004. Faunas del Pérmico y Permo-Triásico de Uruguay: Bioestratigrafía, Paleobiogeografía y Sistemática. Universidad de la República, PhD Dissertation, 215 p.

Piñeiro, G. \& Ubilla, M. 2003. Unidades Pérmico-Triásicas en la Cuenca Norte: paleontología y ambientes. In: G. Veroslavsky; M. Ubilla \& S. Martínez (eds.) Cuencas Sedimentarias de Uruguay: Geología, Paleontología y Recursos Minerales, Mesozoico, Facultad de Ciencias, p. 35-51.

Piñeiro, G.; Marsicano, C. \& Damiani, R. 2007a. Mastodonsaurid temnospondyls from the Upper Permian-Lower Triassic of Uruguay: the earliest record from South America. Acta Palaeontologica Polonica, 52(4):695-703.

Piñeiro, G.; Marsicano, C. \& Lorenzo, N. 2007b. A new temnospondyl from the Permo-Triassic Buena Vista Formation of Uruguay. Palaeontology, 50:627-640.

Piñeiro, G.; Rojas, A. \& Ubilla, M. 2004. A new procolophonoid (Reptilia: Parareptilia) from the Upper Permian of Uruguay. Journal of Vertebrate Paleontology, 24:814-821.

Piñeiro, G.; Verde, M.; Ubilla, M. \& Ferigolo, J. 2003. First basal synapsids ("pelycosaurs") from South America, Late Permian?Early Triassic of Uruguay. Journal of Paleontology, 77:389392.

Reisz, R.R. \& Scott, D. 2002. Owenetta kitchingorum, sp.nov., a small parareptile (Procolophonia: Owenettidae) from the Lower Triassic of South Africa. Journal of Vertebrate Paleontology, 22:244-256.

Rubidge, B.S.; Johnson, M.R.; Kitching, J.W.; Smith, R.; Keyser, A.W. \& Groenewald, G.H. 1995. An introduction to the biozonation of the Beaufort Group. In: B.S. Rubidge (ed.) Biostratigraphy of the Beaufort Group (Karoo Supergroup), South African Committee for Stratigraphy, p. 1-2.

Scherer, C.M.; Faccini, U.F. \& Lavina, E.L. 2000. Arcabouço estratigráfico do Mesozóico da Bacia do Paraná. In: M. Holz \& L.F. De Ros (eds.) Geologia do Rio Grande do Sul, UFRGS, p. 335-354.

Schoch, R.R. \& Milner, A.R. 2000. Stereospondyli. In: H.-D. Sues (ed.) Handbuch der Paläoherpetologie, Teil 3B. Verlag Dr. Friedrich Pfeil, $202 \mathrm{p}$

Sennikov, A.G. 1996. Evolution of the Permian and Triassic tetrapod comunities of Eastern Europe. Palaeogeography, Palaeoclimatology, Palaeoecology, 120:331-351.

Sennikov, A.G. \& Golubev, V.K. 2006. Vyazniki Biotic Assemblage of the Terminal Permian. Palaeontological Journal, 40:475481.

Shishkin, M.A. 1967. A brachyopid labyrinthodont from the Triassic of the Russian Platform. International Geological Review, 9:93-108.

Shishkin, M.A.; Sennikov, A.G.; Novikov, V. \& Ilyina, N.V. 2006. Differentiation of tetrapod communities and some aspects of biotic events in the Early Triassic of Eastern Europe. Palaeontological Journal, 1:3-12.

Sidor, C.A.; O'Keefe, F.R.; Damiani, R.J.; Steyer, J.S.; Smith, R.M.H.; Larsson, H.C.E.; Sereno, P.C.; Ide, O. \& Maga, A. 2005. Permian tetrapods from the Sahara show climatecontrolled endemism in Pangaea. Nature, 434:886-889.

Smith, R. \& Ward, P.D. 2001. Pattern of vertebrate extinctions across an event bed at the Permian-Triassic boundary in the Karoo Basin of South Africa. Geology, 29:1147-1150.

Smith, R. \& Botha, J. 2005. The recovery of terrestrial vertebrate diversity in the South African Karoo Basin after the EndPermian extinction. Comptes Rendu Palevol, 4:555-568.

Smith, R.; Rubidge, B. \& Sidor, C. 2006. A new burnetiid (Therapsida: Biarmosuchia) from the Upper Permian of South Africa and its biogeographic implications. Journal of Vertebrate Paleontology, 26:331-343.

Steiner, M.B.; Eshet, Y.; Rampino, M.R. \& Schwindt, D.M. 2003. Fungal abundance spike and the Permian-Triassic boundary in the Karoo Supergroup (South Africa). Palaeogeography, Palaeoclimatology, Palaeoecology, 194:405-414.

Surkov, M.V.; Kalandadze, N. \& Benton, M.J. 2005. Lystrosaurus georgi, a dicynodont from the Lower Triassic of Russia. Journal of Vertebrate Paleontology, 25:402-413.

Ventura Santos, R.; Souza, P.; Souza de Alvarenga, C.J.; Dantas, E.L.; Martins Pimentel, M.; Gouveia de Oliveira, C. \& Medeiros de Araújo, L. 2006. Shrimp U-Pb zircon dating and palynology of bentonitic layers from the Permian Irati Formation, Paraná Basin, Brazil. Gondwana Research, 9: 456463.

Ward, P.D.; Montgomery, D.R. \& Smith, R.M. H. 2000. Altered river morphology in South Africa related to the PermianTriassic extinction. Science, 289:1740-1743.

Ward, P.D.; Botha, J.; Buick, R.; De Kock, M.O.; Erwin, D.H.; Garrison, G.H.; Kirschvink, J.L. \& Smith, R. 2005. Abrupt and gradual extinction among Late Permian land vertebrates in the Karoo Basin, South Africa. Science, 307:709-714.

Warren, A.A. 1999. Karoo tupilakosaurid: a relict from Gondwana. Transactions of the Royal Society of Edinburgh, Earth Sciences, 89:145-160.

Warren, A.A. \& Marsicano, C. 2000. A phylogeny of the Brachyopoidea (Temnospondyli, Stereospondyli). Journal of Vertebrate Paleontology, 20:462-483.

Warren, A.A.; Damiani, R. \& Yates, A.M. 2006. The South African stereospondyl Lydekkerina huxleyi (Tetrapoda, Temnospondyli) from the Lower Triassic of Australia. 
Geological Magazine, 143:877-886.

Watson, D.M.S. 1962. The evolution of the labyrinthodonts. Philosophical Transactions of the Royal Society of London, B, 245:219-265.

Yates, A.M. 1999. The Lapillopsidae: a new family of small temnospondyls from the early Triassic of Australia. Journal of Vertebrate Paleontology, 19: 302-320.

Yates, A.M. \& Warren, A.A. 2000. The phylogeny of the 'higher' temnospondyls (Vertebrata: Choanata) and its implications for the monophyly and origins of the Stereospondyli. Zoological Journal of the Linnean Society, 128:77-121.

Zerfass, E.; Lavina, E.L.; Schultz, C.L.; García, A.J.V.; Faccini, U.F. \& Chemale, F. Jr. 2003. Sequence stratigraphy of continental Triassic strata of Southernmost Brazil: a contribution to Southwestern Gondwana palaeogeography and palaeoclimate. Sedimentary Geology, 161:85-105.

Received in June, 2007; accepted in October, 2007. 